\title{
Middle East respiratory syndrome coronavirus: current knowledge and future considerations
}

\author{
M. Malik ${ }^{1}$, A.A. Elkholy ${ }^{1}$, W. Khan ${ }^{\text {, }}$ S. Hassounah ${ }^{2}$, A. Abubakar ${ }^{1}$, N. Tran Minh ${ }^{7}$ and P. Mala ${ }^{1}$
}

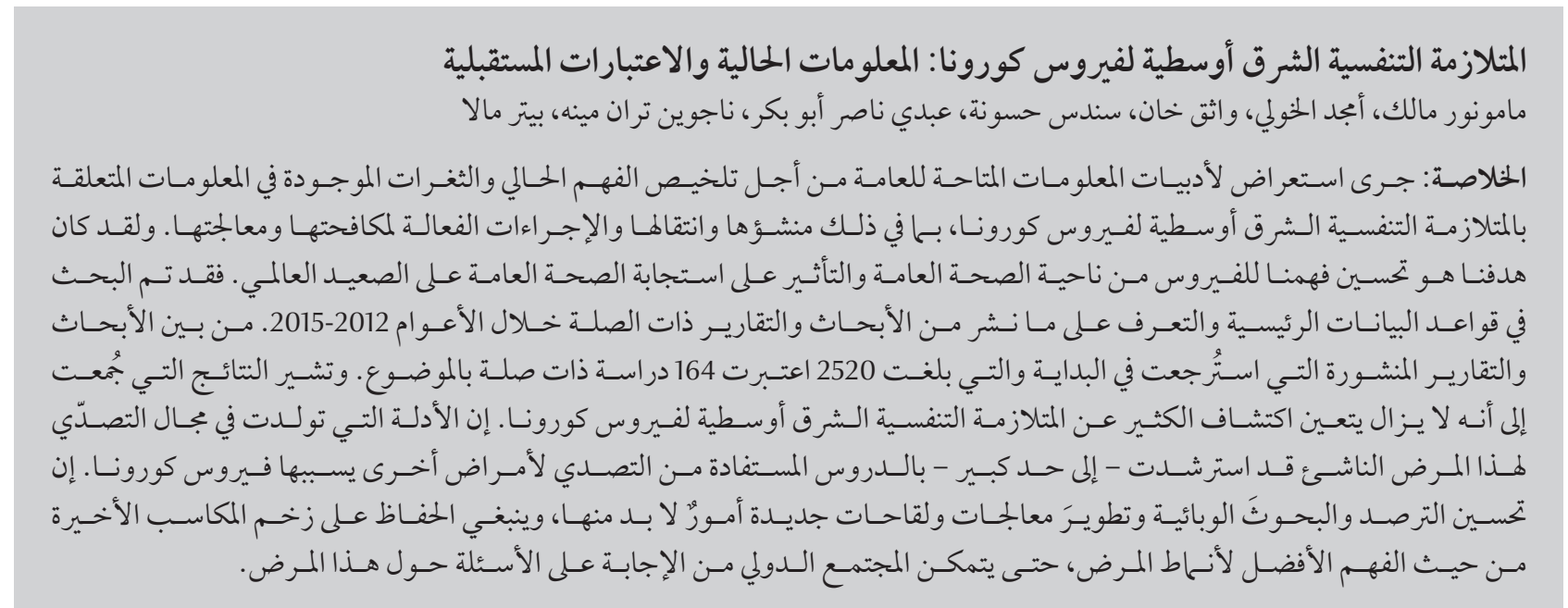

ABSTRACT A literature review of publically available information was undertaken to summarize current understanding and gaps in knowledge about Middle East respiratory syndrome coronavirus (MERS-CoV), including its origin, transmission, effective control measures and management. Major databases were searched and relevant published papers and reports during 2012-2015 were reviewed. Of the 2520 publications initially retrieved, 164 were deemed relevant. The collected results suggest that much remains to be discovered about MERS-CoV. Improved surveillance, epidemiological research and development of new therapies and vaccines are important, and the momentum of recent gains in terms of better understanding of disease patterns should be maintained to enable the global community to answer the remaining questions about this disease.

\section{Coronavirus du syndrome respiratoire du Moyen-Orient : connaissances actuelles et perspectives}

RÉSUMÉ Une analyse documentaire des informations publiques disponibles a été entreprise afin de passer en revue les connaissances et les lacunes actuelles sur le coronavirus du syndrome respiratoire du MoyenOrient (MERS-CoV), notamment sur son origine, la transmission, les mesures de lutte efficaces et la prise en charge. Notre objectif est d'améliorer la compréhension du virus au plan de la santé publique, et d'agir sur I'intervention de santé publique internationale. Nous avons effectué des recherches dans les principales bases de données et avons examiné les articles et rapports publiés pertinents pour la période 2012-2015. Sur les 2520 articles et rapports publiés initialement sélectionnés, 164 études ont été jugées pertinentes. Les résultats recueillis indiquent qu'il reste encore beaucoup à apprendre sur le MERS-CoV. II est impératif d'améliorer la surveillance, de procéder à des recherches épidémiologiques et de mettre au point de nouveaux traitements et vaccins. De même, il est nécessaire de maintenir l'élan suscité par les récentes découvertes en matière de compréhension améliorée du tableau épidémiologique, afin de permettre à la communauté mondiale de répondre aux questions jusqu'à présent sans réponse à propos de cette maladie. 


\section{Introduction}

Middle East respiratory syndrome is a viral illness caused by a novel human coronavirus. Named Middle East respiratory syndrome coronavirus (MERS-CoV), it was first reported in Saudi Arabia in 2012 (1). As of 5 September 2015, 1554 laboratoryconfirmed cases had been reported to World Health Organization (WHO) (2), with a high case fatality rate. At least 552 deaths have been reported thus far, accounting for over one third of all cases (Figure 1) (2). This rate is higher than that of severe acute respiratory syndrome coronavirus (SARS), estimated at $15 \%$, and is strongly ageand sex-dependent (3).To date, 26 countries on four continents $(2,4)$ have been affected. Since the initial outbreak in 2012, MERS-CoV has not been a rapidly spreading global contagion, but (based on modelling exercises) the possibility remains that it will evolve to pandemic proportions. The source of the virus in sporadic cases remains unknown although bats and camels have been implicated (5). MERS$\mathrm{CoV}$ often presents as a lower respiratory tract disease associated with fever, breathing difficulty and pneumonia that can progress to acute respiratory distress, cough, multi-organ failure and death (6). The incidence and mortality are sex-and age-dependent respectively $(7,8)$, and management is a challenge owing to the lack of any proven effective therapy $(9,10)$.

Much has been written in the past few years in terms of epidemiological patterns, gene sequencing, immunogenicity and the animal-human and human-human interfaces. Consequently, a myriad of literature has been produced, much of it providing evidence to answer questions about the origin, transmission, effective control measures and management of the disease.

We reviewed the publicly available literature and aggregated current data relevant to MERS-CoV to identify gaps in the knowledge in order to improve public health understanding of the virus and better shape the global public health response.

\section{Methods}

We searched the databases Medline, Embase Classic+Embase, Science Direct, Global Health, Cochrane database, WHO Library and Information Network for knowledge database (WHOLIS), the Index Medicus for the Eastern Mediterranean Region (IMEMR), the Stephen B Thacker CDC Library (CDC Library), the European Centre for Disease Prevention and Control (ECDC) and the National Institute for Clinical Excellence (NICE) databases on 19 April 2015 for "Middle East respiratory syndrome coronavirus" [MESH] OR "MERS-CoV" [keyword] OR "MERS" [keyword] for publications between 2012 and 2015. We retrieved 2520 papers, which were screened to result in 164 that were deemed relevant (Figure 2). Papers were included if they addressed MERS-CoV in any context. These were supplemented by iterative

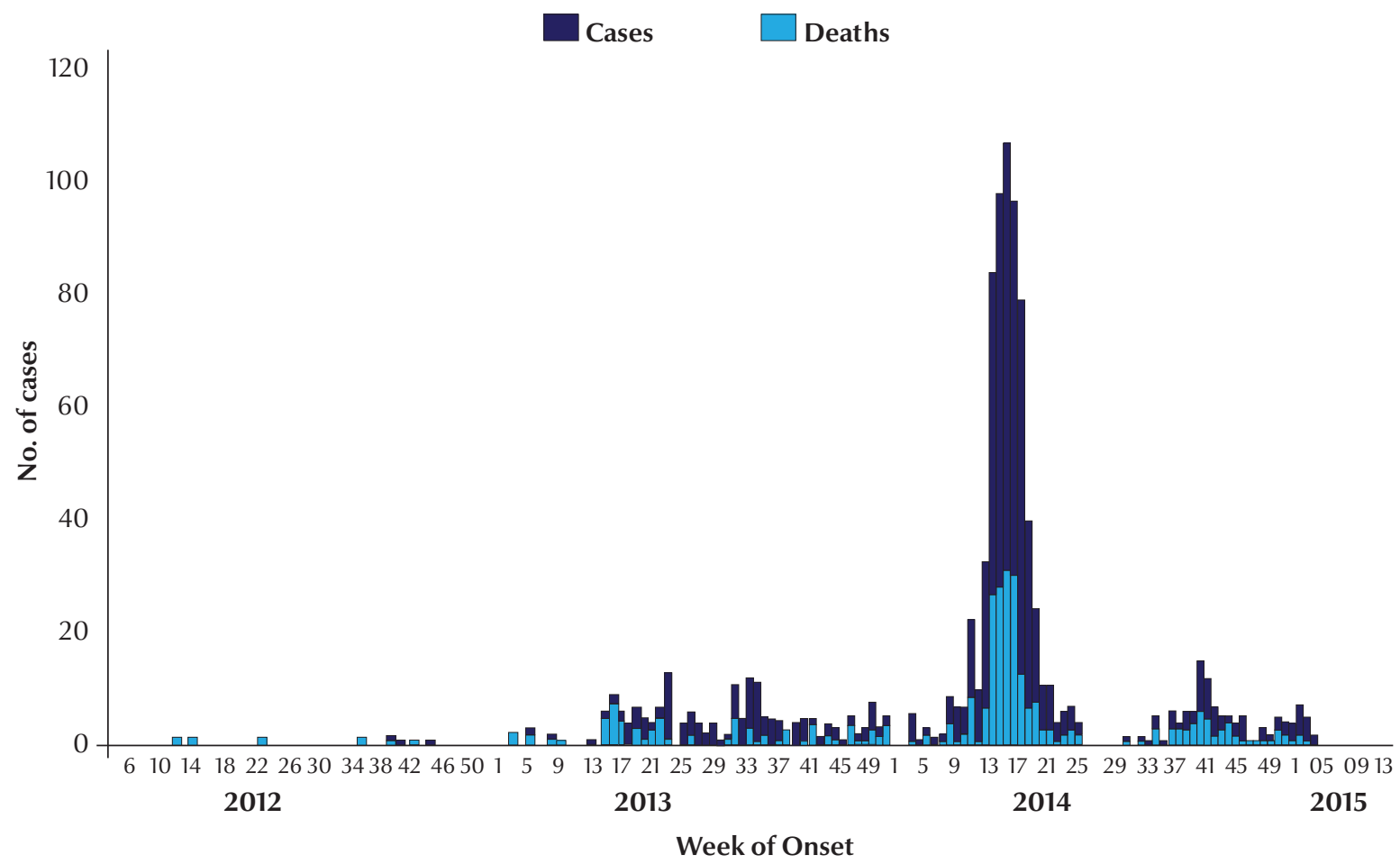

Figure 1 MERS-CoV global epidemic: human cases as of 5 September $2015(n=971)(2)$ 


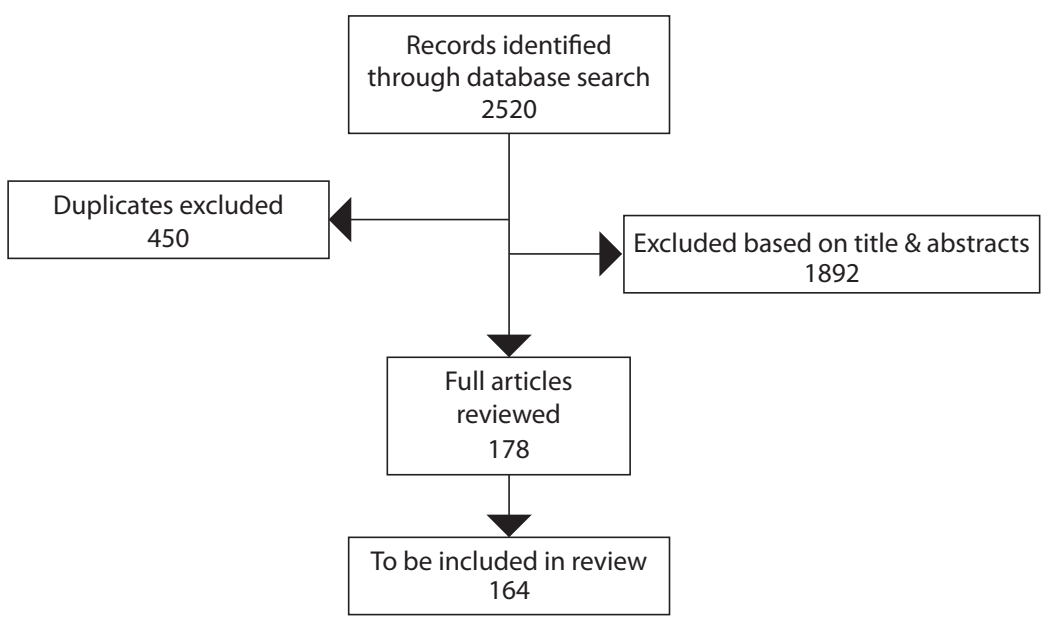

Figure 2 Flow chart of literature search showing number of records

reviews of the reference lists of relevant published papers in addition to grey literature identified in $\mathrm{WHO}$ reports.

The following information was extracted and summarized: the origin and reservoir of the virus, epidemiology (clinical and demographic characteristics of the virus), exposure, transmission and risk factors for human infection, therapeutic options, effective infection control measures in health care facilities, seroprevalence in high-risk groups, appropriate serological diagnostic assays and effective public health control measures.

\section{Results}

\section{Origin and reservoir of the} virus

The putative candidate source of MERS-CoV is vespertilionid bats (11). Genetic material from specimens taken from MERS-CoV patients shows that MERS-CoV also has a close genetic relation with coronaviruses found in bats in southern China (12), South Africa (13), Europe (14,15), Thailand (16), Mexico (17), Ghana (15) and Saudi Arabia (18) as well as in other species, such as hedgehogs (19). Bats are thought to be the origin of a zoonotic infection transmitted to dromedary camels, and ultimately from camels to humans through close contact (20, 21). Camels have been acting as mixing vessels for viruses from different hosts $(11,22)$, and they have been shown to have neutralizing antibodies against MERS-CoV (23-31). In camels testing positive for MERS-CoV, juvenile dromedary camels are often virus-positive,

\section{Cases Deaths}

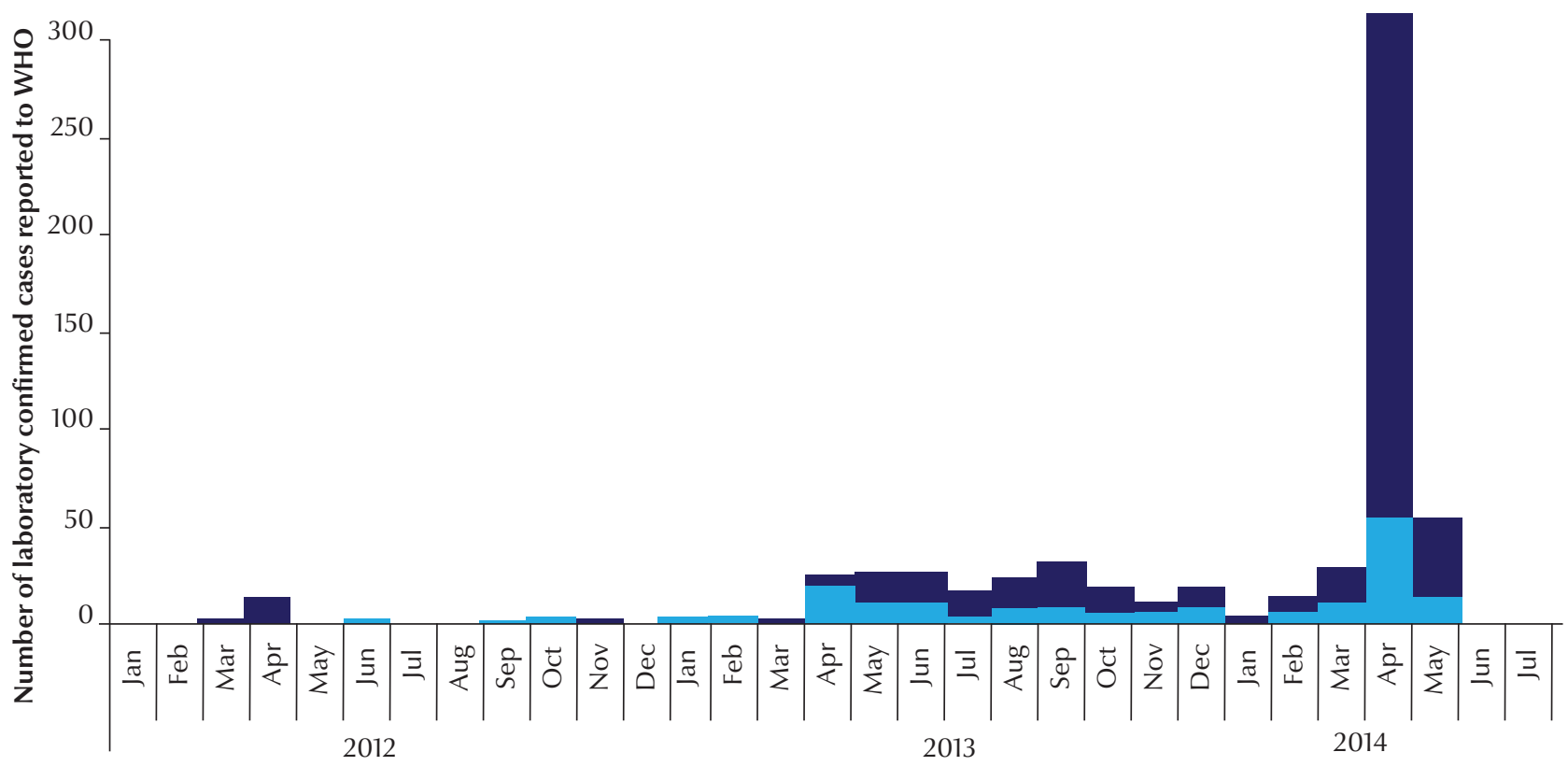

Month of Onset

Figure 3 Epidemic curve of laboratory confirmed MERS-CoV cases globally by outcome, as of 8 May $2014(n=536)(40)$ 
while older camels are more likely to be seropositive and virus-negative (25, 27,31-33). Serological studies have also indicated that camels can be the natural hosts of MERS-CoV infections, which were established long before the first human MERS-CoV cases were identified $(26,28,34,35)$.

\section{Epidemiology of MERS-CoV}

\section{Demographic characteristics}

MERS-CoV was first reported in Saudi Arabia in September 2012 (1). The first infected human died of respiratory and renal failure (36); the virus was traced back to April 2012, when an outbreak of pneumonia resulting in two deaths occurred among health care workers in an intensive care unit in Jordan (37). To date, 26 countries on four continents have been affected. In the Middle East: Egypt, Islamic Republic of Iran, Jordan, Kuwait, Lebanon, Oman, Qatar, Saudi Arabia, United Arab Emirates and Yemen; in Africa: Algeria and Tunisia; in Europe: Austria, France, Germany, Greece, Italy, the Netherlands, Turkey and the United Kingdom; in Asia: China, the Republic of Korea, Malaysia, Philippines and Thailand; and in North America: the United States of America $(2,4)$.

The initial predominance of male cases reported in earlier outbreaks has now levelled out to a more balanced sex distribution $(7,8)$. A pattern of seasonal distribution seems to be emerging in the majority of cases (38): April 2012 (Jordan, Zarqa public health hospital) (39), April-May 2013 (Saudi Arabia, Al-Hasa outbreak) (8) and April-May 2014 (Jeddah and United Arab Emirates outbreaks) (40) (Figure 3). The incidence of cases in the spring raises the possibility of a seasonal cycle. This is possibly linked to the fact that camels give birth in the spring (March) (23, 32,41 ).

\section{Clinical characteristics}

The current WHO case definition (42) identifies probable cases as having febrile acute respiratory illness with clinical, radiological or histopathological evidence of pulmonary parenchymal disease, cough, requirement for hospitalization with suspicion of lower respiratory tract involvement, history of direct contact with a probable or confirmed case, and history of residence or recent travel to a country where MERS-CoV is known to be circulating in dromedary camels or where human infections have recently occurred. This spectrum of signs warrants laboratory testing, where seroconversion in 2 samples by screening and a neutralization assay confirms a case. Although the initial cases of MERS-CoV were detected among patients admitted for severe pneumonia, individuals with mild or no symptoms have also been reported $(2-4,44)$. Thus, WHO has highlighted the importance of also seeking out asymptomatic cases.

The clinical presentation of MERS$\mathrm{CoV}$ infection can range from asymptomatic to very severe pneumonia with acute respiratory distress and multi-organ failure, resulting in death. The clinical course is more severe in immunocompromised patients (6), (although recent case reports indicate that some recover) $(45,46)$, and in pregnant women, where infection has been shown to result in stillbirths. The clinical course is more likely to be mild in individuals without underlying medical conditions (7,47-49).

In its typical form, MERS-CoV infection presents as fever, cough, sore throat and myalgia, which can then be followed by dyspnoea that progresses rapidly to pneumonia, often requiring extracorporeal membrane oxygenation or other organ support. One-third of patients have gastrointestinal symptoms (1,6,7,36,39,50-52). Chest radiography and computed tomography findings are generally consistent with viral pneumonitis and acute respiratory distress syndrome (7,8,47,53-55), and laboratory findings include leukopenia, particularly lymphopenia $(1,7,8,39,56)$.

The median time from symptom onset to hospitalization is 4 days (range $0-16$ ), from symptom onset to admission to an intensive care unit is 5 days (range 1-15) and from symptom onset to death is 11.5 days (range 4-298) $(44,50)$. The time spent in hospital, terminating in either discharge or death was relatively short (median, 7.0 days and 9.0 days, respectively) (44).

\section{Viral characteristics and classifica- tion}

Deep sequencing methods were used predominantly for genome analysis during the emergence of MERS-CoV $(14,22)$.It is predicted that MERS-CoV encodes at least 10 open-reading frames bracketed by 5 ' and 3 ' untranslated regions (57,58). Structural proteins include the spike (S), envelope (E), membrane (M) and nucleocapsid (N) $(59,60)$, and non-structural proteins include a papain-like protease (61-63), transmembrane domains, a 3C-like protease (61), an RNA-dependent RNA polymerase, a helicase and an exonuclease $(14,59,64,65)$.

Genomes collected from samples of MERS-CoV over the past 3 years show close genetic similarity (66): an alignment of 56 complete or near-complete genomes sampled between 2012 and 2014 differed by $0.00-0.38 \%$ (66) (Figure 4).

MERS-CoV belongs to a lineage $\mathrm{C}$ within the Betacornavirus found in both humans and camels that are different from other Betacoronavirus that have infected human such as SARS, and the endemic known human Betacoronavirus: OC43, HKU1, NL63, and 229E.

\section{Pandemic potential}

Estimations and modelling studies show that a pandemic is unlikely; however, concern remains (67). The estimate is based mainly on calculation of the basic reproduction number (R0) - the average number of infections 
caused by 1 infected individual in a fully susceptible population (68-71) - from publicly available data. The estimation from the modelling studies suggests that current data are consistent with 2 scenarios: "(i) a sustained epidemic in an animal reservoir with sporadic spillover into humans, and (ii) sustained human-human transmission causing a slowly growing human epidemic" (44). Incomplete case contact tracing, limited testing and clinically defined cases in the absence of laboratory confirmation might affect some R0 calculations and make it difficult to identify patterns in disease incidence.

\section{Transmission and infection control}

Although transmission originated from zoonotic events $(1,20,37)$, clusters of human-human transmission of MERS-CoV are now well documented $(30,36,38,55,72-82)$, predominantly among people in health care facilities and within households $(3,7,8,22,30$, $36,38,43,44,55,72-75,77,79-86)$. Consequently, human-human transmission of MERS-CoV has been defined as sporadic, intrafamilial and health care-associated. The current pattern of disease is a combination of repeated introduction of the virus from camels to people, resulting in limited, unsustained, human-human transmission $(40,87)$.

MERS-CoV RNA has been identified in the milk, nasal secretions and faeces of camels (88). When MERS$\mathrm{CoV}$ is introduced into camel, goat or cow milk, it can survive for prolonged periods (89); however, pasteurization removes its infectivity (90). Accordingly, the consumption of undercooked or raw animal products, including meat and milk, imposes a high risk. Animal products processed appropriately through proper cooking or pasteurization are safe for consumption but should be handled with care to avoid cross-contamination with uncooked foods (91). In aerosol tests, MERSCoV viability decreased by $89 \%$ at $70 \%$ relative humidity but by only $7 \%$ at $40 \%$

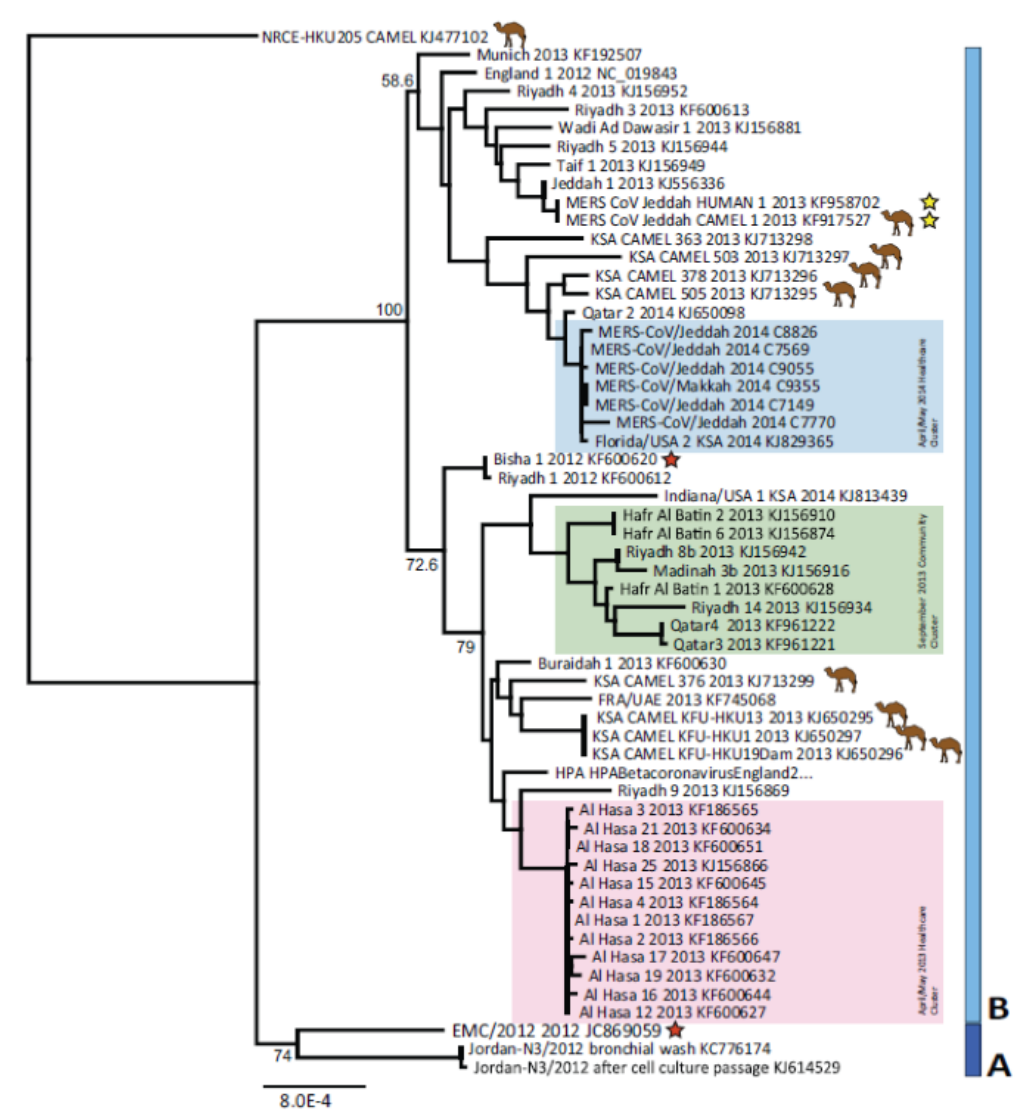

Figure 4 The genetic relationship between all near-complete and complete MERSCoV genome nucleotides (67)

humidity $(89,90)$. This can have implications in terms of optimal levels for room temperature/humidity control for detected cases to limit spread of the virus. Thus, as a general precaution, WHO recommends general hygiene measures, including regular hand-washing, especially after touching animals; avoiding touching the eyes, nose or mouth with the hands; and avoiding contact with sick animals, particularly for anyone visiting farms, markets, barns or other places where camels are present $(87,91)$. Wearing protective gowns and gloves while handling animals is also recommended $(91,92)$.

As many of the cases have occurred in health care settings $(8,81,84,93)$, it is important that all health care workers practice appropriate infection control measures and apply standard precautions consistently (92) when taking care of patients who are suspected of having or have been confirmed as having MERS-CoV infection (36), especially contact precautions and eye protection. Application of droplet precautions is also required when caring for patients with symptoms of acute respiratory infection, and airborne infection isolation precautions should be applied if necessary (36).

\section{Therapeutic options}

In the absence of pathogen-specific interventions, treatment of hospitalized patients remains supportive. Treatment is directed at relieving symptoms and includes rest, fluid and analgesics, and mainly depends on the provision of organ support and management of complications $(10,44,94)$. Broad-spectrum antimicrobial agents, antivirals (94-96), interferon- $\alpha 2 b$ (96) and antifungal agents have been known to be used to minimize the risk of co-infection with opportunistic pathogens (44). There 
have been some research advances in terms of development and registration of drugs for human use against emerging infectious agents $(97,98)$; however, progress has been slow.

Promising treatment approaches currently emerging in the scientific literature (66) include the novel molecule K22, which targets viral replication without cellular toxicity (99). It targets viral MERS-CoV $3 \mathrm{C}$ protease (79) and the interface between the MERS-CoV receptor-binding domain (RBD) and the receptor by inhibiting the enzymatic function of dipeptidyl peptidase 4 (DPP4) (100). An experimental recombinant nanoparticle vaccine candidate has been produced (101) based on MERS-CoV S monoclonal antibodies directed towards the $S$ protein, and this holds promise for use as a therapeutic and prophylactic agent (102-104). A further vaccine candidate has been shown to elicit antibodies in mice $(105,106)$, and another is a conserved peptide that may provide the basis for an epitopedirected universal vaccine (107).

\section{Molecular diagnostic assays}

The viral genome was initially detected in human clinical samples with primers targeting highly conserved regions of the coronavirus genome (44); however, validated (108) real-time reverse transcriptase polymerase chain reaction (rtRT-PCR) assays are now recommended, as they been shown to be both sensitive and specific. Multiple assays are also widely used, i.e. those targeting a region upstream of the $\mathrm{E}$ gene or regions within open reading frame $1 \mathrm{~b}$ (ORF 1b) (nsp14 protein) (108), ORF 1a (nsp6 protein) (109) and the nucleocapsid protein gene (4).

\section{Discussion}

A great deal of evidence has been generated in response to this emerging disease, guided mainly by lessons learnt from responses to other coronavirus diseases such as severe acute respiratory syndrome (SARS). Although much has become clearer with regard to MERS-CoV epidemiological patterns, gene sequencing, immunogenicity and animal-human and human-human interfaces, there is undoubtedly much more to be discovered about the operationality of the virus.

WHO, through the Global Alert and Response Disease Outbreak News releases and close proactive contact with the ministries of health of Member States, has so far managed to contain the disease and avoid pandemic spread. Challenges remain, however, owing to a lack of sufficiently detailed data on patient notifications and publications, resulting in a slowing down of evidence-based diagnostic support for outbreak investigations (110). For a more thorough understanding of the clinical significance and epidemiology of MERS-CoV, detailed data from sampling, laboratory analyses, and clinical and epidemiological studies are required to improve the quality of support during outbreaks.

Risk communication to the public is also important, especially among people who have contact with camels. Rapidly and comprehensively updated data case definitions and guidelines for investigations, research study protocols, travel advice, risk assessments and summary updates via purpose-built coronavirus-focused information portals have been instrumental in curbing MERS-CoV. The WHO has played a leading role in all of the above and recommends that such a system of data transparency and continuous updates adopted and linked at country level.

Public health authorities, clinicians and academic scientists must work even more closely together to discover and report relevant data to public health authorities through official channels (111). Global understanding of the epidemiology and treatment for MERS-CoV has improved since the novel outbreak in 2012; however, greater attention should be paid to more-effective prevention. Further emphasis should include upstream prevention through better interdisciplinary collaboration and communication on all aspects of health care for humans, animals and the environment to improve capacity to identify potential pathogens before they become human threats and to prevent their emergence where possible (111). Some initiatives are showing promise: the One Health Initiative (112) approach, for example, provides a means for interdisciplinary collaboration and communication in all aspects of health care for humans, animals and the environment and could promote the alignment of priorities in global health.

Much remains unknown about MERS-CoV. Surveillance, epidemiological research and the development of new therapies and vaccines are important, and the momentum of recent gains should be maintained to enable the global community to answer the remaining questions about this disease. Below is a list of questions, which is by no means exhaustive, that remain unanswered based on the review of publicly available literature:

-What is the natural host for MERS$\mathrm{CoV}$ ? And what are the mechanisms for animal-human and human-animal transmission

-What is the route of transmission? And what is the best personal protective gear for use by frontline health care workers as well as those working exposed to camels and other potential reservoirs for the disease (animal-human interface)?

- Does MERS-CoV infection generally result in a subclinical outcome, except in people with comorbidities? And does the high mortality rate primarily reflect infection of patients with substantial co-morbid conditions?

- Are current serological tools sensitive enough to detect the immune response to mild or asymptomatic MERS-CoV infection? 
- Do differences in occupational and environmental circumstances provide a valid explanation for the initial dissimilarity in terms of disease affection? What is the prevalence of underlying disease in the two sexes?

- Does MERS-CoV inhibit interferon induction by novel mechanisms not used by other coronaviruses?

- Does lack of recognition by innate host immune sensors result in high levels of virus in the lung and an imbalanced immune response?

- What is the average duration of MERS-CoV shedding in infected humans, and does it differ with age, sex and occupation?

- What other events occurring in the northern spring may influence the increase in human exposure to MERS-CoV?

- Why does MERS-CoV continue to affect wide areas of Saudi Arabia but in such very low numbers? Do mass gatherings have an as yet unidentified role in the spread of the virus and its subsequent geographical distribution?

\section{Acknowledgements}

Funding: None.

Competing interests: None declared.

\section{References}

1. Zaki AM, van Boheemen S, Bestebroer TM, Osterhaus $\mathrm{AD}$, Fouchier RA. Isolation of a novel coronavirus from a man with pneumonia in Saudi Arabia. N Engl J Med. 2012 Jul;367(19):1814-20.

2. Middle East respiratory syndrome coronavirus (MERS-CoV): summary of current situation, literature update and risk assessment-as of 5 February 2015. Geneva: World Health Organization; 2015 (http://www.who.int/csr/disease/coronavirus_infections/mers-5-february-2015.pdf?ua=1, accessed 10 March 2016).

3. Penttinen PM, Kaasik-Aaslav K, Friaux A, Donachie A, Sudre B, Amato-Gauci AJ, et al. Taking stock of the first 133 MERS coronavirus cases globally - is the epidemic changing? Euro Surveill. 2013 Sep;18(39):1-5.

4. Middle East respiratory syndrome (MERS): countries with labconfirmed MERS cases. Atlanta: Centers for Disease Control and Prevention; 2015 (http://www.cdc.gov/coronavirus/ mers/, accessed 9 March 2016).

5. Memish ZA, Al-Tawfiq JA, Makhdoom HQ, Assiri A, Alhakeem RF, Albarrak A, et al. Respiratory tract samples, viral load, and genome fraction yield in patients with Middle East respiratory syndrome. J Infect Dis. 2014;210(10):1590-4.

6. Arabi YM, Arifi AA, Balkhy HH, Najm H, Aldawood AS, Ghabashi A, et al. Clinical course and outcomes of critically ill patients with Middle East respiratory syndrome coronavirus infection. Ann Intern Med. 2014;160(6):389-97.

7. Assiri A, Al-Tawfiq J, Al-Rabeeah A, Al-Rabiah F, Al-Hajjar S, Al-Barrak A, et al. Epidemiological, demographic, and clinical characteristics of 47 cases of Middle East respiratory syndrome coronavirus disease from Saudi Arabia: a descriptive study. Lancet Infect Dis. 2013;13(9):752-61.

8. Assiri A, McGeer A, Perl T, Price C, Al Rabeeah A, Cummings D, et al. Hospital outbreak of Middle East Respiratory Syndrome Coronavirus. N Engl J Med. 2013;369(5):407-16.

9. Al-Tawfiq Jaffar AMA. What are our pharmacotherapeutic options for MERS-CoV? Expert Rev Clin Pharmacol. 2014;7(3):235-8.

10. Momattin H, Mohammed K, Zumla A, Memish ZA, Al-Tawfiq JA. Therapeutic options for Middle East respiratory syndrome coronavirus (MERS-CoV)-possible lessons from a systematic review of SARS-CoV therapy. Int J Infect Dis. 2013;17(10):e7928.

11. Corman VM, Ithete NL, Richards LR, Schoeman MC, Preiser W, Drosten C, et al. Rooting the phylogenetic tree of middle East respiratory syndrome coronavirus by charac- terization of a conspecific virus from an African bat. J Virol. 2014;88(19):11297-303.

12. Yang Li Wu Z, Ren X, Yang F, Zhang J, He G, et al. MERS-related betacoronavirus in Vespertilio superans bats, China. Emerg Infect Dis. 2014;20(7):1260-2.

13. Ithete NL, Stoffberg S, Corman VM, Cottontail VM, Richards LR, Schoeman MC, et al. Close relative of human Middle East respiratory syndrome coronavirus in bat, South Africa. Emerg Infect Dis. 2013;19(10):1697-9.

14. Cotten M, Lam TT, Watson SJ, Palser AL, Petrova V, Grant $P$, et al. Full-genome deep sequencing and phylogenetic analysis of novel human betacoronavirus. Emerg Infect Dis. 2013;19(5):736-742. Epub 2013/05/23.

15. Annan A, Baldwin HJ, Corman VM, Klose SM, Owusu M, Nkrumah EE, et al. Human betacoronavirus 2c EMC/2012related viruses in bats, Ghana and Europe. Emerg Infect Dis. 2013;19(3):456-9. Epub 2013/04/30.

16. Wacharapluesadee S, Sintunawa C, Kaewpom T, Khongnomnan K, Olival K, Epstein J, et al. Group C betacoronavirus in bat guano fertilizer, Thailand. Emerg Infect Dis. 2013;19(8):1349-52.

17. Anthony SJ, Ojeda-Flores R, Rico-Chavez O, Navarrete-Macias I, Zambrana-Torrelio CM, Rostal MK, et al. Coronaviruses in bats from Mexico. J Gen Virol. 2013;94(Pt 5):1028-38. Epub 2013/02/01.

18. Memish ZA, Mishra N, Olival KJ, Fagbo SF, Kapoor V, Epstein $\mathrm{JH}$, et al. Middle East respiratory syndrome coronavirus in bats, Saudi Arabia. Emerg Infect Dis. 2013;19(11):1819-23. Epub 2013/11/12.

19. Corman VM, Kallies R, Philipps H, Gopner G, Muller MA, Eckerle I, et al. Characterization of a novel betacoronavirus related to middle East respiratory syndrome coronavirus in European hedgehogs. J Virol. 2014;88(1):717-24. Epub 2013/10/18.

20. Azhar El, El-Kafrawy SA, Farraj SA, Hassan AM, Al-Saeed MS, Hashem AM, et al. Evidence for camel-to-human transmission of MERS coronavirus. N Engl J Med. 2014;370(26):2499-505. Epub 2014/06/05.

21. Memish ZA, Cotten M, Meyer B, Watson SJ, Alsahafi AJ, Al Rabeeah AA, et al. Human infection with MERS coronavirus after exposure to infected camels, Saudi Arabia, 2013. Emerg Infect Dis. 2014;20(6):1012-5.

22. Cotten M, Watson SJ, Kellam P, Al-Rabeeah A, Makhdoom H, Assiri A, et al. Transmission and evolution of the Middle East respiratory syndrome coronavirus in Saudi Arabia: a descriptive genomic study. Lancet. 2013;382(9909):1993-2002. 
23. Reusken $C B$, Haagmans BL, Müller MA, Gutierrez C, Godeke GJ, Meyer B, et al. Middle East respiratory syndrome coronavirus neutralising serum antibodies in dromedary camels: a comparative serological study. Lancet Infect Dis. 2013;13(10):859-66.

24. Chu DK, Poon LL, Gomaa MM, Shehata MM, Perera RA, Abu Zeid D, et al. MERS coronaviruses in dromedary camels, Egypt. Emerg Infect Dis. 2014;20(6):1049-53.

25. Hemida MG, Chu DK, Poon LL, Perera RA, Alhammadi MA, Ng $\mathrm{HY}$, et al. MERS coronavirus in dromedary camel herd, Saudi Arabia. Emerg Infect Dis. 2014;20(7):1231-4.

26. Corman VM, Jores J, Meyer B, Younan M, Liljander A, Said MY, et al. Antibodies against MERS coronavirus in dromedary camels, Kenya, 1992-2013. Emerg Infect Dis. 2014;20(8):1319-22.

27. Raj VS, Farag EA, Reusken CB, Lamers MM, Pas SD, Voermans $\mathrm{J}$, et al. Isolation of MERS coronavirus from dromedary camel, Qatar, 2014. Emerg Infect Dis. 2014;20(8):1339-42.

28. Meyer B, Müller MA, Corman VM, Reusken CB, Ritz D, Godeke $\mathrm{G}$, et al. Antibodies against MERS coronavirus in dromedary camels, United Arab Emirates, 2003 and 2013. Emerg Infect Dis. 2014;20(4):552-9.

29. Reusken CBEM, Messadi L, Feyisa A, Ularamu H, Godeke GJ, Danmarwa A, et al. Geographic distribution of MERS coronavirus among dromedary camels, Africa. Emerg Infect Dis. 2014. http://dx.doi.org/10.3201/eid2008.140590.

30. Yavarian JRF, Shadab A, Soroush M, Gooya M, Azad T. Cluster of Middle East respiratory syndrome coronavirus infections in Iran, 2014. Emerg Infect Dis. 2015;21(2):362-4.

31. Nowotny N, Kolodziejek J. Middle East respiratory syndrome coronavirus (MERS-CoV) in dromedary camels, Oman, 2013. Euro Surveill. 2014;19(16):pii=20781. DOI: http://dx.doi. org/10.2807/1560-7917.ES2014.19.16.20781

32. Hemida MG. PRA, Wang P,Alhammadi MA, Siu LY, Li M, Poon LL, Saif L, Alnaeem A, Peiris M. Middle East Respiratory Syndrome (MERS) Coronavirus Seroprevalance in domestic livestock in Saudi Arabia, 2010 to 2013. Euro Surveill. 2013;18(50):pii=20828.DOI:http://dx.doi.org/10.2807/15607917.ES2014.19.23.20828

33. Reusken CB, Messadi L, Feyisa A, Ularamu H, Godeke GJ, Danmarwa A, et al. Geographic distribution of MERS coronavirus among dromedary camels, Africa. Emerg Infect Dis. 2014;20(8):1370-4

34. Muller MA, Corman VM, Jores J, Meyer B, Younan M, Liljander A, et al. MERS coronavirus neutralizing antibodies in camels, Eastern Africa, 1983-1997. Emerg Infect Dis. 2014;20(12):20935.

35. Alexandersen S, Kobinger GP, Soule G, Wernery U. Middle East respiratory syndrome coronavirus antibody reactors among camels in Dubai, United Arab Emirates, in 2005. Transbound Emerg Dis. 2014;61(2):105-8.

36. Memish ZZA, Al-Hakeem R, Al-Rabeeah A, Stephens G. Family cluster of middle east respiratory syndrome coronavirus infections. N Engl J Med. 2013;368(26):2487-94.

37. de Groot RJ, Baker SC, Baric RS, Brown CS, Drosten C, Enjuanes $\mathrm{L}$, et al. Middle East respiratory syndrome coronavirus (MERS(oV): announcement of the Coronavirus Study Group. J Virol. 2013;87(14):7790-2. Epub 2013/05/17.

38. Al-Tawfiq JA, Memish ZA. Middle East respiratory syndrome coronavirus: epidemiology and disease control measures. Infect Drug Resist. 2014;7:281-7.

39. Hijawi B, Abdallat M, Sayaydeh A, Alqasrawi S, Haddadin A. Jaarour Net al. Novel coronavirus infections in Jordan, April 2012: epidemiological findings from a retrospective investigation. East Mediterr Health J. 2013;19(1):S12-8.
40. Middle East Respiratory Syndrome Coronavirus. (ERS-CoV summary updates. Geneva: World Health Organization; 2014 (http://www.who.int/csr/disease/coronavirus_infections/ archive_updates/en/, accessed 9 March 2016).

41. Alagaili AN, Briese T, Mishra N, Kapoor V, Sameroff S, Burbelo PD, et al. Middle East respiratory syndrome coronavirus infection in dromedary camels in Saudi Arabia. MBio. 2014;5(2):e00884-14.

42. Middle East respiratory syndrome coronavirus (MERS-CoV): case definition for reporting to WHO. Geneva: World Health Organization; 2014 (http://www.who.int/csr/disease/coronavirus_infections/case_definition/en/, accessed 9 March 2016).

43. Al-Tawfiq JA, Ziad AM. Middle East respiratory syndrome novel corona MERS-CoV infection. Epidemiology and outcome update. Saudi Med J. 2013 Oct;34(10):911-4.

44. The WHO MERS-CoV Research Group. State of Knowledge and Data Gaps of Middle East Respiratory Syndrome Coronavirus (MERS-CoV) in Humans. PLoS Curr. 2013;12(5)

45. Alghamdi MMF, Awn N, Shalhoub S. MERS CoV infection in two renal transplant recipients: Case report. Am J Transplant. 2015;15(4):1101-4.

46. Shalhoub S, AlZahrani A, Simhairi R, Mushtaq A. Successful recovery of MERS CoV pneumonia in a patient with acquired immunodeficiency syndrome: A case report. J Clin Virol. 2015;62(0):69-71.

47. Das Karuna MLY, Enani M, AlJawder S, Singh R, Bashir S, et al. CT Correlation With Outcomes in 15 Patients With Acute Middle East Respiratory Syndrome Coronavirus. AJR Am J Roentgenol. 2015;204(4):736-42.

48. Payne DC, Iblan I, Alqasrawi S, et al. Stillbirth During Infection With Middle East Respiratory Syndrome Coronavirus. J Infect Dis. 2014;209(12):1870-2.

49. Memish Z, Al-Tawfiq J, Assiri A, AlRabiah F, Al Hajjar S, Albarrak A, et al. Middle East respiratory syndrome coronavirus disease in children. Pediatr Infect Dis J. Sept 2014 33(9):904-906.

50. Bermingham A, Chand MA, Brown CS, Aarons E, Tong C, Langrish $\mathrm{C}$, et al. Severe respiratory illness caused by a novel coronavirus, in a patient transferred to the United Kingdom from the Middle East, September 2012. Euro Surveill. 2012 Oct;17(40) :pii=20290. (http://www.eurosurveillance.org/ ViewArticle.aspx?Articleld=20290).

51. Khalid M, Khan B, Rabiah FA, Alismaili R, Saleemi S, RehanKhaliq AM, et al. Middle Eastern Respiratory Syndrome Corona Virus (MERS CoV): case reports from a tertiary care hospital in Saudi Arabia. Ann Saudi Med. 2014;34(5):396-400.

52. Guery BPJ, El-Mansouf L, Sejourne C, Ettahar N, Lemaire X, et al. Clinical features and viral diagnosis of two cases of infection with Middle East Respiratory Syndrome coronavirus: a report of nosocomial transmission. Lancet. 2013;381(9885):2265-72.

53. Tsiodras S, Baka A, Iliopoulos D, et al. A case of imported Middle East Respiratory Syndrome coronavirus infection and public health response, Greece, April 2014. Euro Surveill. 2014 Apr;19(16):20782.

54. Premila Devi J, Noraini W, Norhayati R, Chee Kheong C, Badrul A, Zainah S, et al. Laboratory-confirmed case of Middle East respiratory syndrome coronavirus (MERS-CoV) infection in Malaysia: preparedness and response, April 2014. Euro Surveill. 2014 May;19(18):20797.

55. Saad M, Omrani AS, Baig K, Bahloul A, Elzein F, Matin MA, et al. Clinical aspects and outcomes of 70 patients with Middle East respiratory syndrome coronavirus infection: a single-center experience in Saudi Arabia. Int J Infect Dis. 2014;29(0):301-6.

56. Drosten C, Muth D, Corman VM, Hussain R, Al Masri M, HajOmar W, et al. An observational, laboratory-based study of 
outbreaks of middle East respiratory syndrome coronavirus in Jeddah and Riyadh, kingdom of Saudi Arabia, 2014. Clin Infect Dis : an official publication of the Infectious Diseases Society of America. 2015;60(3):369-77. Epub 2014/10/18.

57. Raj VS, Mou H, Smits SL, Dekkers DH, Muller MA, Dijkman $R$, et al. Dipeptidyl peptidase 4 is a functional receptor for the emerging human coronavirus-EMC. Nature. 2013;495(7440):251-4. Epub 2013/03/15.

58. Raj VS, Osterhaus AD, Fouchier RA, Haagmans BL. MERS: emergence of a novel human coronavirus. Curr Opin Virol. 2014;5:58-62. Epub 2014/03/04.

59. van Boheemen S, de Graaf M, Lauber C, Bestebroer TM, Raj VS, Zaki AM, et al. Genomic characterization of a newly discovered coronavirus associated with acute respiratory distress syndrome in humans. MBio. 2012;3(6): Epub 2012/11/22.

60. Song FFR, Provacia LB, Volz A, Eickmann M, Becker S, et al. Middle east respiratory syndrome coronavirus spike protein delivered by modified vaccinia virus ankara efficiently induces virus-neutralizing antibodies. J Virol. 2013;87(21):11950-4.

61. Kilianski A, Mielech AM, Deng X, and Baker SC. Assessing activity and inhibition of Middle East respiratory syndrome coronavirus papain-like and 3C-like proteases using luciferase-based biosensors. J Virol. 2013;87(21):11955-62. Epub 2013/08/30

62. Lin MH, Chuang SJ, Chen CC, Cheng SC, Cheng KW, Lin CH, et al. Structural and functional characterization of MERS coronavirus papain-like protease. J Biomed Sci. 2014;21:54.

63. Lin MH, Chuang SJ, Chen CC, Cheng S, Cheng KW, Lin CH, et al. Structural and functional characterization of MERS coronavirus papain-like protease. J Biomed Sci. 2014 Jun;21:54.

64. Niemeyer DZT, Muth D, Zielecki F, Horvath G, Suliman $\mathrm{T}$, et al. Middle east respiratory syndrome coronavirus accessory protein $4 \mathrm{a}$ is a type I interferon antagonist. J Virol. 2013;87(22):12489-95.

65. Mou HRV, Van Kuppeveld S, Rottier PJ, Haagmans B, Bosch B. The receptor binding domain of the new Middle East respiratory syndrome coronavirus maps to a 231-residue region in the spike protein that efficiently elicits neutralizing antibodies. J Virol. 2013;87(16):9379-83.

66. Mackay IM, Arden KE. Middle East respiratory syndrome: An emerging coronavirus infection tracked by the crowd. Virus Res. 2015 Apr;202:60-8.

67. Majumder MS, Rivers C, Lofgren E, Fisman D. Estimation of MERS-coronavirus reproductive number and case fatality rate for the spring 2014 Saudi Arabia outbreak: insights from publicly available data. PLoS Curr. 2014 Dec;18:6.

68. Bauch CT, Oraby T. Assessing the pandemic potential of MERS-CoV. Lancet. 2013;382(9893):662-4.

69. Breban R, Riou J, Fontanet A. Interhuman transmissibility of Middle East respiratory syndrome coronavirus: Estimation of pandemic risk. Lancet. 2013;382(9893):694-9.

70. Lessler J, Rodriguez-Barraquer I, Cummings DAT, Garske T, Van Kerkhove M, Mills H, et al. Estimating Potential Incidence of MERS-CoV Associated with Hajj Pilgrims to Saudi Arabia, 2014. PLoS Curr. 2014;6. doi:10.1371/currents.outbreaks.c5c9c9abd636164a9b6fd4dbda974369

71. Cauchemez S, Fraser C, Kerkhove M, Donnelly C, Riley S, Rambaut A, et al. Middle East respiratory syndrome coronavirus: quantification of the extent of the epidemic, surveillance biases, and transmissibility. Lancet Infect Dis. 2014;14(1):50-6.

72. Memish ZA, Cotten M, Watson SJ, Kellam P, Zumla A, Alhakeem RF, et al. Community case clusters of Middle East respiratory syndrome coronavirus in Hafr Al-Batin, Kingdom of Saudi Arabia: a descriptive genomic study. Int J Infect Dis. 2014;23:63-8.
73. Omrani AS, Matin MA, Haddad Q, Al-Nakhli D, Memish ZA, Albarrak AM. A family cluster of Middle East respiratory syndrome coronavirus infections related to a likely unrecognized asymptomatic or mild case. Int J Infect Dis. 2013;17(9):e668-72.

74. Reuss A, Litterst A, Drosten C, Seilmaier M, Bohmer M, Graf $\mathrm{P}$, et al. Contact investigation for imported case of Middle East respiratory syndrome, Germany. Emerg Infect Dis. 2014;20(4):620-5.

75. Al-Abdallat MM, Payne DC, Alqasrawi S, Rha B, Tohme RA, Abedi GR, et al. Hospital-associated outbreak of Middle East respiratory syndrome coronavirus: A serologic, epidemiologic, and clinical description. Clin Infect Dis. 2014;59(9):1225-33.

76. Kapoor M, Pringle K, Kumar A, Dearth S, Liu L, Lovchik J, et al. Clinical and laboratory findings of the first imported case of middle east respiratory syndrome coronavirus to the United States. Clin Infect Dis. 2014;59(11):1511-8.

77. Abroug F, Slim A, Ouanes-Besbes L, Hadj Kacem M-A, Dachraoui F, Ouanes I, et al. Family cluster of Middle East respiratory syndrome coronavirus infections, Tunisia, 2013. Emerg Infect Dis. 2014;20(9):1527-30.

78. Aburizaiza AS, Mattes FM, Azhar El, Hassan AM, Memish ZA, Muth D, et al. Investigation of anti-middle East respiratory syndrome antibodies in blood donors and slaughterhouse workers in Jeddah and Makkah, Saudi Arabia, fall 2012. J Infect Dis. 2014;209(2):243-6.

79. Cotten M, Watson SJ, Zumla Al, Makhdoom HQ, Palser AL, Ong $\mathrm{SH}$, et al. Spread, circulation, and evolution of the Middle East respiratory syndrome coronavirus. MBio. 2014;5(1)

80. Drosten C, Meyer B, Muller M, Corman V, Al-Masri M, Hossain $\mathrm{R}$, et al. Transmission of MERS-coronavirus in household contacts. N Engl J Med. 2014;371(9):828-35.

81. Hall AJ, Tokars JI, Badreddine S, Saad Z, Furukawa E, Al Masri $M$, et al. Health care worker contact with MERS patient, Saudi Arabia. Emerg Infect Dis. 2014;20(12):2148-51.

82. Memish ZA, Al-Tawfiq JA, Makhdoom HQ, Al-Rabeeah AA, Assiri A, Alhakeem RF, et al. Screening for Middle East respiratory syndrome coronavirus infection in hospital patients and their healthcare worker and family contacts: a prospective descriptive study. Clin Microbiol Infect. 2014;20(5):469-74.

83. Memish ZA, Assiri A, Almasri M, Alhakeem RF, Turkestani A, Al Rabeeah AA, et al. Prevalence of MERS-CoV nasal carriage and compliance with the Saudi health recommendations among pilgrims attending the 2013 Hajj. J Infect Dis. 2014;210(7):1067-72.

84. Oboho IK, Tomczyk SM, Al-Asmari A, Banjar A, Al-Mugti $\mathrm{H}$, Aloraini M, et al. 2014 MERS-CoV outbreak in Jeddah - a link to health care facilities. N Engl J Med. 2015;372(9):846-54.

85. Health Protection Agency (HPA) UK Novel Coronavirus Investigation team. Evidence of person-to-person transmission within a family cluster of novel coronovirus infections, United Kingdom, February 2013. Euro Surveill. 2013 Mar;18(11):20427.

86. Puzelli S, Azzi A, Santini MG, Di Martino A, Facchini M, Castrucci M, et al. Investigation of an imported case of Middle East Respiratory Syndrome Coronov (MERS-CoV) infection in Florence, Italy, May to June 2013. Euro Surveill. 2013 Aug;18(34) DOI: http://dx.doi.org/10.2807/1560-7917. ES2013.18.34.20564

87. Rapid risk assessment: Severe respiratory disease associated with Middle East respiratory syndrome coronavirus (MERS-CoV) Eleventh update, 21 August 2014. Stockholm: European Centre for Disease Prevention and Control; 2014 (http://ecdc.europa.eu/en/publications/_layouts/forms/ Publication_DispForm.aspx?List=4f55ad51-4aed-4d32-b960af70113dbb90\&ID=1152, accessed 10 March 2016).

88. Reusken CB, Ababneh M, Raj VS, Meyer B, Eljarah A, Abutarbush S, et al. Middle East Respiratory Syndrome coronavirus 
(MERS-CoV) serology in major livestock species in an affected region in Jordan, June to September 2013. Euro Surveill. 2013;18(50): 20662.

89. Van Doremalen N, Bushmaker T, Karesh WB, Munster VJ. Stability of Middle East respiratory syndrome coronavirus in milk. Emerg Infect Dis. 2014;20(7):1263-4.

90. van Doremalen N, Bushmaker T, Munster VJ. Stability of Middle East respiratory syndrome coronavirus (MERS-CoV) under different environmental conditions. Euro Surveill. 2013 Sep;18(38):20590.

91. WHO. Update on MERS-CoV transmission from animals to humans, and interim recommendations for at-risk groups-19 June 2014. Geneva: World Health Organization; 2014.

92. Pebody R, Chand MA, Thomas H, Green H, Boddington N, Carvalho C, et al. The United Kingdom public health response to an imported laboratory confirmed case of a novel coronavirus in September 2012. Euro Surveill. 2012;17(40):20292.

93. Al-Abdallat MM, Payne DC, Alqasrawi S, Rha B, Tohme RA, Abedi GR, et al. Hospital-associated outbreak of Middle East respiratory syndrome coronavirus: a serologic, epidemiologic, and clinical description. Clin Infect Dis. 2014;59(9):1225-33.

94. Al-Tawfiq JA, Momattin H, Dib J, Memish ZA. Ribavirin and interferon therapy in patients infected with the Middle East respiratory syndrome coronavirus: an observational study. Int J Infect Dis. 2014;20:42-6.

95. Omrani AS, Saad MM, Baig K, Bahloul A, Abdul-Matin M, Alaidaroos AY, et al. Ribavirin and interferon alfa-2a for severe Middle East respiratory syndrome coronavirus infection: a retrospective cohort study. [Erratum in Lancet Infect Dis. 2015;211(2):13]. Lancet Infect Dis. 2014;14(11):1090-5.

96. Falzarano D, De Witt E, Rasmussen AL, Feldmann F, Okumura A, Scott DP, et al. Treatment with interferon-alpha2b and ribavirin improves outcome in MERS-CoV-infected rhesus macaques. Nat Med. 2013;19(10):1313-7.

97. Dyall J, Coleman CM, Hart BJ, Venkataraman T, Holbrook MR, Kindrachuk J, et al. Repurposing of clinically developed drugs for treatment of Middle East respiratory syndrome coronavirus infection. Antimicrob Agents Chemother. 2014 Aug;58(8):4885-93.

98. de Wilde AH, Jochmans D, Posthuma CC, ZevenhovenDobbe JC, van Nieuwkoop S, Bestebroer TM, et al. Screening of an FDA-approved compound library identifies four smallmolecule inhibitors of Middle East respiratory syndrome coronavirus replication in cell culture. Antimicrob Agents Chemother. 2014 Aug;58(8):4875-84.

99. Lundin A, Dijkman R, Bergstrom T, Kann N, Adamiak B, Hannoun $C$, et al. Targeting membrane-bound viral RNA synthesis reveals potent inhibition of diverse coronaviruses including the Middle East respiratory syndrome virus. PLoS Pathog. 2014;10(5) e1004166. doi:10.1371/journal.ppat.1004166

100. Kawalec P, Mikrut A, Łopuch S. The safety of dipeptidyl peptidase-4 (DPP-4) inhibitors or sodium-glucose cotransporter 2
(SGLT-2) inhibitors added to metformin background therapy in patients with type 2 diabetes mellitus: a systematic review and meta-analysis. Diabetes Metab Res Rev. 2014;30(4):269-83.

101. Coleman CM, Liu YV, Mu H, Taylor JK, Massare M, Flyer DC, et al. Purified coronavirus spike protein nanoparticles induce coronavirus neutralizing antibodies in mice. Vaccine. 2014;32(26):3169-74.

102. Ying T, Du L, Ju TW, Prabakaran P, Lau CCY, Lu L, et al. Exceptionally potent neutralization of Middle East respiratory syndrome coronavirus by human monoclonal antibodies. J Virol. 2014;88(14):7796-805.

103. Tang XC, Agnihothram SS, Jiaoa Y, Stanhope J, Graham RL, Peterson EC, et al. Identification of human neutralizing antibodies against MERS-CoV and their role in virus adaptive evolution. Proc Natl Acad Sci USA. 2014 May;111(19):E2018-26.

104. Zhang N, Jiang S, Du L. Current advancements and potential strategies in the development of MERS-CoV vaccines. Expert Rev Vaccines. 2014;13(6):761-74.

105. Almazan F, DeDiego ML, Sola I, Zuñiga S, Nieto-Torres JL, Marquez-Jurado S, et al. Engineering a replication-competent, propagation-defective Middle East respiratory syndrome coronavirus as a vaccine candidate. MBio. 2013;4(5):e00650-13.

106. Du L, Kou Z, Ma C, Tao X, Wang L, Zhao G, et al. A Truncated receptor-binding domain of MERS-CoV spike protein potently inhibits MERS-CoV infection and induces strong neutralizing antibody responses: implication for developing therapeutics and vaccines. PLoS One. 2013;8(12) e81587. doi:10.1371/journal.pone.0081587.

107. Sharmin R, Islam AB. A highly conserved WDYPKCDRA epitope in the RNA directed RNA polymerase of human coronaviruses can be used as epitope-based universal vaccine design. BMC Bioinformatics. 2014;15:161.

108. Corman VM, Muller MA, Costabel U, Timm J, Binger T, Meyer B, et al. Assays for laboratory confirmation of novel human coronavirus (hCoV-EMC) infections. Euro Surveill. 2012;17(49):pii=20334. (http://www.eurosurveillance.org/ ViewArticle.aspx?Articleld=20334).

109. Corman V, Eckerle I, Bleicker T, Zaki A, Landt O, EschbachBludau $\mathrm{M}$, et al. Detection of a novel human coronavirus by real-time reverse-transcription polymerase chain reaction. Euro Surveill. 2012;17(39) :pii=20285. (http://www.eurosurveillance.org/ViewArticle.aspx?Articleld=20285).

110. de Sousa R, Reusken C, Koopmans M. MERS coronavirus: data gaps for laboratory preparedness. J Clin Virol. 2014;59(1):4-11.

111. McCloskey B, Dar O, Zumla A, Heymann D. Emerging infectious diseases and pandemic potential: status quo and reducing risk of global spread. Lancet Infect Dis. 2014;14(10):1001-10.

112. One Health Initiative will unite human and veterinary medicine. One Health Initiative; 2015 (http://www.onehealthinitiative.com/index.php, accessed 4 September 2016). 